\title{
COMBINED EFFECT OF THE ESSENTIAL OIL FROM Chenopodium ambrosioides AND ANTILEISHMANIAL DRUGS ON PROMASTIGOTES OF Leishmania amazonensis
}

\author{
Lianet MONZOTE(1), Ana Margarita MONTALVO(1), Ramón SCULL(2), Migdalia MIRANDA(2) \& Juan ABREU(2)
}

\begin{abstract}
SUMMARY
To date, there are no vaccines against Leishmania, and chemotherapy remains the mainstay for the control of leishmaniasis. The drugs of choice used for leishmaniasis therapy are significantly toxic, expensive and with a growing frequency of refractory infections. Because of these limitations, a combination therapy is the better hope. This work demonstrates that the essential oil from Chenopodium ambrosioides shows a synergic activity after incubation in conjunction with pentamidine against promastigotes of Leishmania amazonensis. However, an indifferent effect has been found for combinations of meglumine antimoniate or amphotericin B and the essential oil.
\end{abstract}

KEYWORDS: Leishmania amazonensis; Chenopodium ambrosioides; Combination therapy.

The leishmaniases are a diverse group of diseases caused by protozoan parasites of the genus Leishmania ${ }^{15}$. The diseases affect about two million people per annum, with approximately 350 million individuals at risk worldwide. The control of leishmaniasis remains a problem. The interruption of zoonotic infection is difficult and no vaccines exist ${ }^{8}$.

Pentavalent antimonials are still the mainstay of therapy for leishmaniasis in most of the world. Recommended secondary drugs include amphotericin B and pentamidine. However, these agents have some disadvantages: parenteral mode of administration, long duration of therapy, toxic effects, cost and parasite resistance ${ }^{11,12}$. On the basis of these considerations, the study of new drugs for leishmaniases treatment is strictly necessary.

Natural products are often overlooked in antiprotozoal chemotherapy. Plants have been used traditionally in the treatment of leishmaniases, in particular against cutaneous disease ${ }^{8}$. Our previous studies have shown that the essential oil from Chenopodium ambrosioides (Chenopodiaceae) has a promising activity against promastigotes and intracellular amastigotes of Leishmania amazonensis and prevent the development of lesion in BALB/c mice with experimental cutaneous leishmaniasis ${ }^{16}$.

After increased unresponsiveness to most of the monotherapeutic regimens, the combination therapy has found new scope in the treatment of both cutaneous and visceral leishmaniasis ${ }^{7}$. Additionally, the combination of antileishmanial drugs could reduce the potential toxic side effects and prevent drug resistance. For those reasons, it is important to critically evaluate the role of combination therapy as new data $^{14}$. In this study, we studied the utility of combination treatment between the essential oil and the currently used antileishmanial drugs on promastigotes of L. amazonensis.

C. ambrosioides was collected in Pharmacy and Foods Institute, Havana's University, Cuba, in July 2001. A voucher specimen (No. 4639) is kept at the Experimental Station of Medicinal Plants "Dr. Juan Tomás Roig", Cuba. The essential oil was obtained by distillation, using a Clevenger's apparatus, of the aerial parts of the plant, as previously described ${ }^{16}$. The antileishmanial agents used in the present work were meglumine antimoniate (Rhône-Poulenc Rorer, Mexico), amphotericin B (IMEFA, Havana City, Cuba) and pentamidine (Richet S.A., Buenos Aires, Argentina).

The strain of L. amazonensis (MHOM/77BR/LTB0016) was kindly provided by the Department of Immunology, Oswaldo Cruz Foundation, Brazil. The parasites were routinely isolated from mouse lesions and maintained as promastigotes at $26^{\circ} \mathrm{C}$ in Schneider's medium (Sigma Chem. Co., St. Louis, Mo, USA), containing $10 \%$ heat-inactivated foetal bovine serum (Sigma), $200 \mathrm{U}$ penicillin/mL and $200 \mathrm{mg}$ streptomycin/ $\mu \mathrm{L}$ (Sigma). 


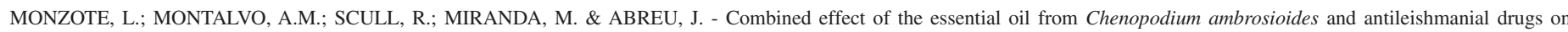
promastigotes of Leishmania amazonensis. Rev. Inst. Med. trop. S. Paulo, 49 (4):257-260, 2007.

The activity against the promastigote form was assessed by the method described by BODLEY et al. ${ }^{5}$. Eleven concentrations of each compound were assayed in quadruplicate. Exponentially growing cells $\left(10^{5}\right.$ promastigotes/mL, $\left.199 \mu \mathrm{L}\right)$ were distributed in 96 -well plates. The tested compounds were added in $1 \mu \mathrm{L}$, and then incubated at $26^{\circ} \mathrm{C}$. After $72 \mathrm{~h}$ of incubation the motility of the promastigotes was analyzed by direct observation under an inverted microscope and the minimal inhibitory concentration (MIC), defined as the lowest concentration of compounds which completely inhibited growth of promastigotes, was determined. The parasites were incubated for $3 \mathrm{~h}$ with $p$-nitrophenyl phosphate $(20 \mathrm{mg} / \mathrm{mL})$ dissolved in sodium acetate buffer $1 \mathrm{M}$ (BDH, Poole, England), pH 5.5, with 1\% Triton X-100 at $37^{\circ} \mathrm{C}$. The absorbance was determined in an EMS Reader MF Version 2.4-0 spectrophotometer, at a wavelength of $405 \mathrm{~nm}$. The $50 \%$ effective concentration (EC50) was obtained from dose-response curves fit to data by means of the equation for the sigmoidal $\mathrm{E}_{\max }$ model. The motile promastigotes were checked by inverted microscope to eliminate possible modulation of the essential oil on L. amazonensis acid phosphatase activity ${ }^{24}$. A second experiment was carried out using different combinations of the essential oil and each antileishmanial agent. MIC concentrations of each compound were used as the first concentration. The activity (EC50) was measured with the same protocol. All experiments were carried out in triplicate. Results were expressed as mean \pm standard deviation.

Afterwards, the reduction in the EC50 was calculated of each compound in the presence of the other. The result is expressed as the fractional inhibitory concentration (FIC) index, which is assessed as follows: $\mathrm{FIC}=[\mathrm{A}] / \mathrm{EC} 50_{\mathrm{A}}+[\mathrm{B}] / \mathrm{EC} 50_{\mathrm{B}}$, where $\mathrm{EC} 50_{\mathrm{A}}$ and $\mathrm{EC} 50_{\mathrm{B}}$ are the EC50 of each compound alone and $[\mathrm{A}]$ and $[\mathrm{B}]$ are the EC50 of the essential oil and the other compound when are used in combination. An FIC index less than or equal to 0.5 indicates synergy and an index greater than four indicates antagonism. When the FIC index is greater than 0.5 and less than four, indicates indifference ${ }^{14}$.

Finally, an isobologram analysis was performed to demonstrate the synergic effect among drugs (A and B). The concentrations of drugs $\mathrm{A}$ and $\mathrm{B}$ required to produce a defined single-agent effect (EC50), when used as single agents, are placed on the $x$ and $y$ axes in a two-coordinate plot, corresponding to $\left(\mathrm{C}_{\mathrm{A}}, 0\right)$ and $\left(0, \mathrm{C}_{\mathrm{B}}\right)$, respectively. The line connecting these two points is the line of additive. Them, the concentrations of the two drugs used in combination to provide the same effect, denoted as $\left(\mathrm{c}_{\mathrm{A}}, \mathrm{c}_{\mathrm{B}}\right)$, are placed in the same plot. Synergy, additive, or antagonism are indicated when $\left(\mathrm{c}_{\mathrm{A}}, \mathrm{c}_{\mathrm{B}}\right)$ is located below, on, or above the line, respectively ${ }^{26}$.
The essential oil had a MIC and EC50 values of 27.82 and $3.74 \mu \mathrm{g} /$ $\mathrm{mL}$, respectively. The effect on the in vitro growth of $L$. amazonensis, caused by each compound used in this study in an individual manner, and the results obtained when promastigotes were treated with different combinations is showed in Table 1 . The meglumine antimoniate was inactive, which have been reported in the literature ${ }^{17}$. We observed synergy between the essential oil and pentamidine, with a FICI value less than 0.5 , which indicated that the synergism has biological relevance ${ }^{14}$. This result was demonstrated through isobologram analyses (Fig. 1). An indifferent effect was appreciated when the essential oil incubated together with meglumine antimoniate or amphotericin B on promastigotes.

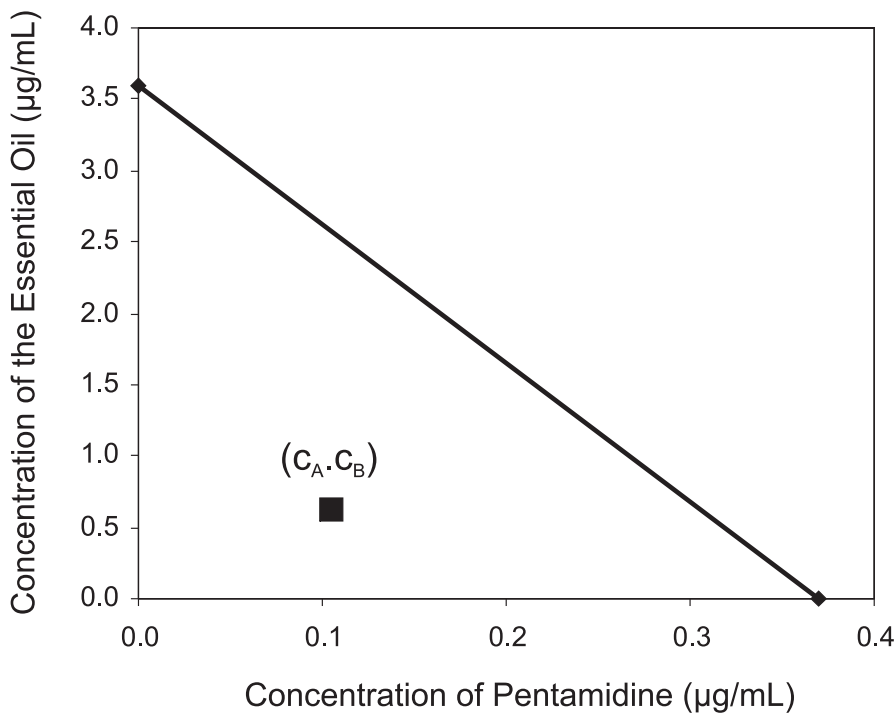

Fig. 1 - Result of isobolograms analysis between the essential oil from Chenopodium ambrosioides and pentamidine. The line indicates synergy, additivity, or antagonism when the point $\left(c_{A}, c_{B}\right)$ is located below, on, or above the line, respectively. The point $\left(c_{A}, c_{B}\right)$ is the result of plotting the EC50 obtained to essential oil and pentamidine when the drugs are used in combination.

Several works have shown that some drugs increased their antileishmanial effect in conjunction with new antileishmanial agents. For example: (i) a combination of paromomycin plus antimony over 60 days cured the diffuse cutaneous leishmaniasis due to L. aethiopica ${ }^{22}$; (ii) clinical trials of allopurinol in combination with pentamidine for visceral leishmaniasis shown better results when used in a combination"; (iii) imiquimod, an immunomodulator, was more efficient when the

Table 1

Activity of each compound studied against promastigotes of L. amazonensis and the results of the combination among studied compounds expressed as FIC index

\begin{tabular}{lcccc}
\hline Compound & $\mathrm{MIC}^{a} \pm \mathrm{SD}^{b}(\mu \mathrm{g} / \mathrm{mL})$ & $\mathrm{EC}_{0} 0^{c} \pm \mathrm{SD}(\mu \mathrm{g} / \mathrm{mL})$ & FIC Index $^{\mathrm{d}}$ & 1.790 \\
\hline Meglumine antimoniate & - & - & 1.622 & Interaction $^{\mathrm{e}}$ \\
Amphotericin B & $0.160 \pm 0.002$ & $0.030 \pm 0.003$ & 0.453 & Indifference \\
Pentamidine & $3.100 \pm 0.010$ & $0.370 \pm 0.010$ & Synergism \\
\hline
\end{tabular}

${ }^{a}$ : MIC - lowest concentration that caused $100 \%$ of inhibition of the parasite growth. ${ }^{b}: \mathrm{SD}$ - standard deviation. ${ }^{c}: \mathrm{EC}_{50}$ - concentration that caused $50 \%$ of inhibition of the parasite growth. ${ }^{d}$ : FIC Index: $[\mathrm{A}] / \mathrm{EC} 50_{\mathrm{A}}+[\mathrm{B}] / \mathrm{EC} 50_{\mathrm{B}}$, where $\mathrm{EC} 50_{\mathrm{A}}$ and $\mathrm{EC} 50_{\mathrm{B}}$ are the EC50 of each compound alone and $[\mathrm{A}]$ and $[\mathrm{B}]$ are the $\mathrm{EC} 50$ of the essential oil and the other compound when are used in combination. The EC50 for each compound alone are given in Table $1 .{ }^{e}$ : Interaction effect combined with the essential oil; Terminology for describing results of combination testing. -: Inactive 
ointment was used in conjunction with antimonials in patients with cutaneous leishmaniasis ${ }^{3}$; (iiii) Different interactions were found in vivo, where the highest potentiation of miltefosine activity was achieved with amphotericin $\mathrm{B}^{19}$.

Synergism among antileishmanial agents might occur in one of several ways. The inhibition of different stages of the same biochemical pathway represents one type of mechanisms of synergism ${ }^{14}$. It is possible that this mechanism explain the synergistic effect found between pentamidine and the essential oil. Multiple mechanism of action had been proposed for pentamidine in kinetoplastid parasites, including DNA binding ${ }^{4,6}$. On the other hand, the exact mechanism of action of the essential oil is not known, but some authors hypothesized that ascaridole (endoperoxide), an active molecule, generates free radicals which can act on parasitic $\mathrm{DNA}^{10,25}$. Although we are thinking in a correlation between DNA binding affinity and synergism found, this may not be the only factor contributing to increase of the antileishmanial activity.

DNA molecules in Leishmania are in a prominent centrally positioned nucleus ${ }^{23}$. The parasite genome is spread over 36 chromosomes and it can be estimated that contains up to 9800 genes $^{13,18}$. Additionally, a single branched mitochondrion is present which may extend the whole length of the cell with a large DNA content, termed kinetoplast ${ }^{23}$. Both DNA pools are implicated in the development of biological phenotype and different processes in Leishmania parasite ${ }^{1,23}$. On the other hand, the essential oil and pentamidine may have different preferences for specific DNA sequences. It could indicate that particular genes or DNA segments may be damaged, which could be related with the high activity observed.

The pentamidine is one of drugs for clinical use in leishmaniasis and it is used in visceral leishmaniasis (cases resistant to antimonial substances) and in cutaneous, diffuse-cutaneous and mucocutaneous leishmaniasis ${ }^{4}$. In Colombia, the efficacy of the drug was demonstrated after repeated administration of $2 \mathrm{mg} / \mathrm{kg}$ every other day for seven days. This regimen was $96 \%$ effective in patients infected with $L$. panamensis $^{21}$. However, ANDERSEN et al. ${ }^{2}$ reported a low cure rate for pentamidine $(35 \%)$ in patients infected with L. braziliensis in Peru. Generally, for cutaneous leishmaniasis, the cure rate associated with low dose of pentamidine given for a short period makes it an attractive alternative to antimonies and the treatment of choice in cases as well as antimonies treatment failure $\operatorname{cases}^{20}$.

The comparison of results across in vivo studies requires careful consideration of the nature of the pathogen, host, host immune status, study design and study endpoints ${ }^{14}$. However, an approach to analysis of intracellular amastigotes and/or in vivo investigations of combinations between the essential oil and pentamidine is specially recommended.

\section{RESUMO}

Efeito combinado do óleo de essência de Chenopodium ambrosioides e drogas anti-leishmaniose nos promastigotas de Leishmania amazonensis

Até hoje não temos vacina contra a Leishmania e a quimioterapia é a indicação para o controle desta doença. Os remédios que hoje utilizamos são tóxicos e muito caros e além disso o resultado não é sempre o desejado. Por isso, uma terapia de combinação é a melhor opção. Este trabalho mostra que o óleo de essência de C. ambrosioides tem atividade sinérgica junto com a pentamidina sobre os promastigotas de L. amazonensis, diferente do resultado da combinação de antimônio de meglumine e anfotericina B e o óleo de essência.

\section{REFERENCES}

1. ACESTOR, N.; MASINA, S.; WALKER, J. et al. - Establishing two-dimensional gels for the analysis of Leishmania proteomes. Proteomics, 2: 877-879, 2002.

2. ANDERSEN, E.M.; CRUZ-SALDARRIAGA, M.; LLANOS-CUENTAS, A. et al. Comparison of meglumine antimoniate and pentamidine for Peruvian cutaneous leishmaniasis Amer. J. trop. Med. Hyg., 72: 133-137, 2005.

3. AREVALO, I.; WARD, B.; MILLER, R. et al. - Successful treatment of drug-resistant cutaneous leishmaniasis in humans by use of imiquimod, an immunomodulator. Clin. infect. Dis., 33: 1847-1851, 2001.

4. BASSELIN, M.; LAWRENCE, F. \& ROBERT-GERO, M. - Pentamidine uptake in Leishmania donovani and $L$. amazonensis promastigotes and axenic amastigotes. Biochem. J., 315: 631-634, 1996.

5. BODLEY, A.L.; McGARRY, M.W. \& SHAPIRO, T.A. - Drug cytotoxicity assay for African trypanosomes and Leishmania species. J. infect. Dis., 172: 1157-1159, 1995.

6. BRENDLE, J.J.; OUTLAW, A.; KUMAR, A. et al. - Antileishmanial activities of several classes of aromatic dications. Antimicrob. Agents Chemother., 46: 797-807, 2002.

7. BRYCESON, A. - Current issues in the treatment of visceral leishmaniasis. Med. Microbiol. Immunol., 190: 81-84, 2001.

8. CROFT, S.L. \& YARDLEY, Y. - Chemotherapy of leishmaniasis. Curr. Pharmaceut. Des., 8: 319-342, 2002.

9. DAS, V.N.; RANJAN, A.; SINHA, A.N. et al. - A randomized clinical trial of low dosage combination of pentamidine and allopurinol in the treatment of antimony unresponsive cases of visceral leishmaniasis. J. Ass. Phycns India, 49: 609-613, 2001.

10. GADANO, A.; GURNI, A.; LOPEZ, P.; FERRARO, G. \& CARBALlO, M. - In vitro genotoxic evaluation of medicinal plant Chenopodium ambrosioides L. J. Ethnopharm., 81: 11-16, 2002.

11. GUERIN, P.J.; OLLIARO, P.; SUNDAR, S. et al. - Visceral leishmaniasis: current status of control, diagnosis, and treatment, and proposed research and development agenda. Lancet infect. Dis., 2: 494-501, 2002.

12. HERWALDT, B.L. - Leishmaniasis. Lancet, 354: 1191-1199, 1999.

13. IVENS, A.C.; LEWIS, S.M.; BAGHERZADEH, A. et al. - A physical map of the Leishmania major Friedlin genome. Genome Res., 8: 135-145, 1998.

14. JOHNSON, M.D.; MACDOUGALL, C.; OSTROSKY-ZEICHNER, L.; PERFECT, J.R. \& REX, J.H. - Combination antifungal therapy. Antimicrob. Agents Chemother., 48: 693-715, 2004.

15. MELBY, P.C. - Recent developments in leishmaniasis. Curr. Opin. infect. Dis., 15: 485490, 2002.

16. MONZOTE, L.; MONTALVO, A.M.; ALMANONNI, A.S. et al. - Activity of the essential oil from Chenopodium ambrosioides grown in Cuba against Leishmania amazonensis. Chemotherapy, 52: 130-136, 2006.

17. MONZOTE, L.; MONTALVO, A.M.; FONSECA, G.L. et al. - In vitro activities of thiadiazine derivatives against Leishmania amazonensis. Arzneimittel-Forschung., 55: 232-238, 2005. 
MONZOTE, L.; MONTALVO, A.M.; SCULL, R.; MIRANDA, M. \& ABREU, J. - Combined effect of the essential oil from Chenopodium ambrosioides and antileishmanial drugs on promastigotes of Leishmania amazonensis. Rev. Inst. Med. trop. S. Paulo, 49 (4):257-260, 2007.

18. MYLER, P.J.; AUDLEMAN, L.; deVOS, T. et al. - Leishmania major Friedlin chromosome 1 has an unusual distribution of protein-coding genes. Proc. nat. Acad. Sci. (Wash.), 96: 2902-2906, 1999.

19. SEIFERT, K. \& CROFT, S.L. - In vitro and in vivo interactions between miltefosine and other antileishmanial drugs. Antimicrob. Agents Chemother., 50: 73-79, 2006.

20. SINGH, S. \& SIVAKUMAR, R. - Challenges and new discoveries in the treatment of leishmaniasis. J. infect. Chemother., 10: 307-315, 2004.

21. SOTO-MANCIPE, J.; GROGL, M. \& BERMAN, J.D. - Evaluation of pentamidine for the treatment of cutaneous leishmaniasis in Colombia. Clin. infect. Dis., 16: 417$425,1993$.

22. TEKLEMARIAM, S.; HIWOT, A.G.; FROMMEL, D. et al. - Aminosidine and its combination with sodium stibogluconate in the treatment of diffuse cutaneous leishmaniasis caused by Leishmania aethiopica. Trans. roy. Soc. trop. Med. Hyg., 88: $334-339,1994$
23. VANNIER-SANTOS, M.A.; MARTINY, A. \& DE SOUZA, W. - Cell Biology of Leishmania spp.: invading and evading. Curr. pharmaceut. Des., 8: 297-318, 2002.

24. VANNIER-SANTOS, M.A.; MARTINY, A.; MEYER-FERNANDES, J.R. \& DE SOUZA, W. - Leishmanial protein kinase $\mathrm{C}$ modulates host cell infection via secreted acid phosphatase. Europ. J. Cell. Biol., 67: 112-119, 1995.

25. VIZOSO PARRA, A.; GARCÍA LÓPEZ, A.; RAMOS RUIZ, A. et al. - Evaluación mutagénica de un extracto fluído con un menstruo etanólico al 70\% de Teloxis ambrosioides L. weber (Apasote). Rev. cuba. Plant. med., 5: 102-105, 2002.

26. ZHAO, L.; WIENTJES, M.J. \& AU, J.L. - Evaluation of combination chemotherapy: integration of nonlinear regression, curve shift, isobologram, and combination index analyses. Clin. Cancer Res., 10: 7994-8004, 2004.

Received: 22 May 2006

Accepted: 17 November 2006 